
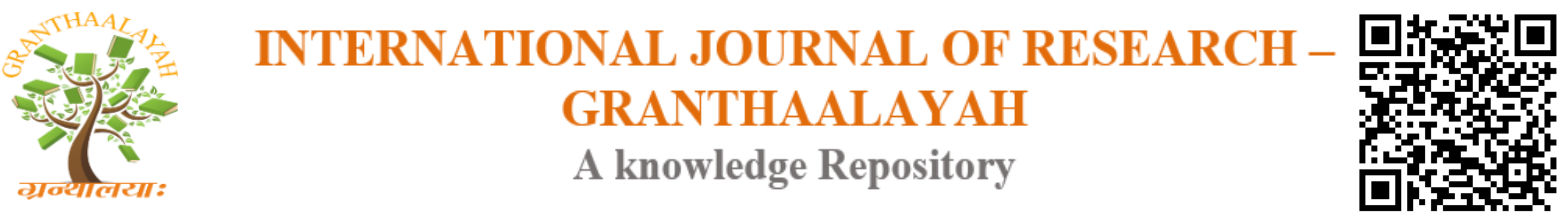

Science

\title{
MANAGEMENT OF GRUDHRASI WITH UNIQUE COMBINATION OF AYURVEDIC HERBAL KWATHA \& AGNIKARMA
}

\author{
Vd.Gauravkumar V. Shaha ${ }^{* 1}$, Vd.Vivek S. Chandurkar ${ }^{2}$ \\ ${ }^{* 1}$ MD (Scholar), Kaychikitsa Department, S.G.R. Ayu. Mahavidyalaya, Solapur, India \\ ${ }^{2}$ MD (Kaychikitsa), Prof.\& H.O.D. of Kaychikitsa Department, S.G.R. Ayu. Mahavidyalaya, \\ Solapur, India
}

\begin{abstract}
Today people are predisposed to various diseases based on their way of living and occupational habits called life style diseases. Orthopedic disorders are one of the mostly exposed to such life style habits. physical inactivity, wrong body posture, occupational posture, long sitting jobs, stresses activity, exposure to continue vibration, post-operative causes, gym, athletes muscular spasm are main contributing factors to orthopedic disorders.

One of the most common orthopedic health problems today is lower back pain which is accompanied most of the time by Sciatica. The present case study is successful Ayurvedic management of a case of "GRUDRASI".
\end{abstract}

Keywords: Grudhrasi; Unique Combination of Ayurvedic Herbal Kwatha; Agnikarma.

Cite This Article: Vd.Gauravkumar V. Shaha, and Vd.Vivek S. Chandurkar. (2017). "MANAGEMENT OF GRUDHRASI WITH UNIQUE COMBINATION OF AYURVEDIC HERBAL KWATHA \& AGNIKARMA.” International Journal of Research - Granthaalayah, 5(9), 224-229. https://doi.org/10.29121/granthaalayah.v5.i9.2017.2235.

\section{Introduction}

Ayurveda described sciatica as Grudhrasi. most of the common Vata-vyadhi observed in majority of people. Grudhrasi word itself describes the disease i.e. "Grudhra" (Eagle) like walking. The disease is caused by vitiation of vata, sometimes even Kapha vitiation along with vata also cause Sciatica.

'Grudhrasi'l is a Ruja pradhana Nanatmaja Vata Vyadhi, intervening with the functional ability of low back \& lower limbs. Grudhrasi cripple the life of patient by causing radiating pain (Sphik-kati-prushtha-uru-janu jangha-pad kramgat vedana) in leg while walking or rest as well.

The symptoms seen in Grudhrasi can be well correlated with "Sciatica" in modern terminology. Sciatica is a very painful condition in which pain begins in lumbar region and radiates along the postero-lateral aspect of thigh and leg. Hence, movement of the affected leg is restricted and 
patient is not able to walk properly. It is particularly seen in most active period of life, involving working class people causing hindrance in routine life.

\subsection{Case Report}

The present case study is successful Ayurvedic management of a case of "GRUDRASI'" (SCIATICA).

A 34 year old Male patient came to us with chief complaint of -

1) Pain radiating in the following manner-

2) Sphik-Kati-Prishtha-Uru-Janu-Jangha-Pad Kramat Vedana.

3) Stambh

4) Toda

5) Muhurmuhu Spandana (Janu Kati Uru Sandhinam)

6) Deha Pravakrata

7) Pad Suptata.

Patient had above complaints since last 1 month.

\subsection{History of Personal Illness}

The patient was normal one month back. Since then patient has been suffering from Pain radiating in the following manner - Sphik-Kati-Prishtha-Uru-Janu-Jangha-Pad Kramat Vedana ( +++) ,Stambh (+), Toda (++), Muhurmuhu Spandana (Janu Kati Uru Sandhinam) (+), Deha Pravakrata (++), Pad Suptata (+). He had tried all kinds of pain killer medicines, but nothing provide relief from his problem, then he came to our hospital - Sheth Sakharam Nemchand Jain Ayurved Rugnalaya, Solapur. For better treatment we admitted him in Ipd section of kaychikitsa department.

\section{ASTAVIDHAPARIKSHAN:}

Nadi $($ pulse $)=84 / \mathrm{min}$.

Mala $($ stool $)=$ Asamyaka

Mutra $($ urine $)=$ Normal

Jeevha $($ tongue $)=$ Ishat saam .

Agni $=$ Normal

Shabda $($ speech $)=$ Normal

Akruti= Madhyama.

$\underline{\text { Bala }}=$ Madhyama.

Koshtha= Madhyama.

Raktadaaba(B.P.) $=120 / 70 \mathrm{~mm}$ of $\mathrm{Hg}$.

\subsection{Examination and Investigation}

- Sakthikshepana-nigraha (SLRT) examination has shown positive at 10 degree of left leg.

- X-RAY LS -spine has shown early Osteo-arthritic changes. 


\section{Materials and Methods}

\subsection{Method}

- Sampling: Simple random case study.

- Center of study: S.S.N.J.Ayurved Rugnalayan, Solapur.

\subsection{Material}

Meshashrungyadi kwatha given in dose of $16 \mathrm{ml}$ with Eranda sneha prakshepa after food b.i.d. and Agnikarma with lohashalaka 2 sittings in 8 days.

Management involve -

1) Ayurveda herbal kwatha-Meshashrungyadi Kwatha ${ }^{3}$

Table 1: Showing internal medicine used in treatment

\begin{tabular}{|l|l|l|}
\hline Sr.no. & Dravya name (latin name) & Dose \\
\hline 1. & Meshashrungi (Gymnema sylvestre ) & $1 \mathrm{gm}$ \\
\hline 2. & Vidnaga (Embelia ribes ) & $1 \mathrm{gm}$ \\
\hline 3. & Gokshur (Tribulus terrestris ) & $1 \mathrm{gm}$ \\
\hline 4. & Ashwagandha (Withania somnifera ) & $1 \mathrm{gm}$ \\
\hline 5. & Eranda (Ricinus communis ) & $1 \mathrm{gm}$ \\
\hline 6. & Bilwa (Aegle marmelos) & $1 \mathrm{gm}$ \\
\hline 7. & Bruhati (Solanum indicum ) & $1 \mathrm{gm}$ \\
\hline 8. & Kantakari (Solanum surattense) & $1 \mathrm{gm}$ \\
\hline
\end{tabular}

\section{Kwath Nirman vidhi:}

Kwath Nirman done as per procedure described in sharangdhara samhita. There are three methods explained in Sharangdhar samhita among them the method in which water is taken 8(i.e $64 \mathrm{ml}$ ) times than coarse herbal powder(i.e $8 \mathrm{gm}$ ) \& then boiled till 1/4th quantity(i.e $16 \mathrm{ml}$ ) of total remain be taken. The raw materials which are to be used are collected from ISO certified company S.S.N.J. Ayurved Rasashala, Solapur. Thus, the Meshashrungyadi Kwath prepared.
Dose
: $16 \mathrm{ml}$ twice in a day
Anupana : Eranda taila $10 \mathrm{ml}-------20 \mathrm{ml} \mathrm{BD}$

Aushadhi sevan kala: Adhobhakt (After Meal)

\section{Agnikarma:}

Agnikarma Sthan: "Antarakandaragulpha,5

Upkarana:Lohashalaka

PROCEDURE DONE WEEKLY i.e. two times

\section{Observation \& Result}

Clinical examination of the patients revealed regression of Pain, Stambh,Toda,Muhurmuhu Spandana (Janu Kati Uru Sandhinam),Deha Pravakrata,Pad Suptata within 8 days. 
Table 2: showing result of tretment (before and after )

\begin{tabular}{|l|l|l|}
\hline SYMPTOMS & BEFORE TREATMENT & AFTER TREATMENT \\
\hline PAIN & +++ & NIL \\
\hline STAMBHA & + & NIL \\
\hline TODA & ++ & NIL \\
\hline $\begin{array}{l}\text { MUHURMUHUR } \\
\text { SPANDAN }\end{array}$ & + & NIL \\
\hline DEHA PRAVAKRATA & ++ & NIL \\
\hline PAD SUPTATA & + & NIL \\
\hline
\end{tabular}

\section{Discussion}

The patient is PORTER by profession so long standing HARD WORK is leads to hetu of grudhrasi.

1) Ahar-improper and irregular diet,tea,cold drinks causes the disturbance of tri-doshas.

2) Vihar-long standing job, exertion immediately after meal.

3) vaya- Madhyam avastha

4) Mansika nidan- Atichinta,santapa

\section{SAMPRAPTI}

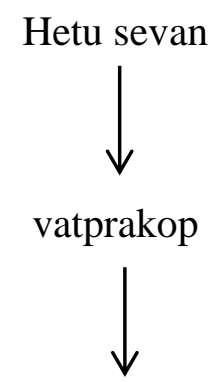

Srotas rukshata

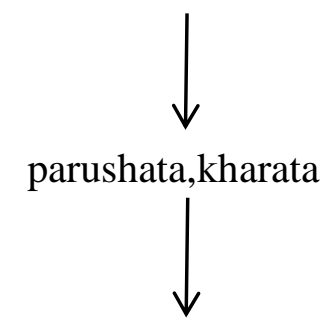

Rikta srotasanche thikani vayupuran-

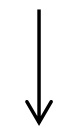

Grudhrasi. 
Management involve -

1) MODE OF ACTION OF KWATH

Table 3: showing mode of action of kwatha ${ }^{6}$

\begin{tabular}{|l|l|l|}
\hline Sr.no. & Dravya & Action \\
\hline 1. & Meshashrungi & Shothahar,vedanahar \\
\hline 2. & Vidnaga & Nadisaunstan balya \\
\hline 3. & Gokshur & Vedanasthapan,vatshaman \\
\hline 4. & Ashwagandha & Mastishkashamak, Shothahar,vedanasthapan \\
\hline 5. & Eranda & Vatshamak, balya,vedanasthapan, angmardprashman \\
\hline 6. & Bilwa & Naditantu shamak,vedanashapan, shothahara \\
\hline 7. & Bruhati & Vedanasthapan, dipan,pachan, grahi,krimighna \\
\hline 8. & Kantakari & Sadnya prabodhan, vatahar,Vedanasthapan \\
\hline
\end{tabular}

\section{2) MODE OF ACTION OF AGNIKARMA}

In Chikitsa of Grudhrasi Ayurveda mainly concentrate on bringing back the viated vata dosha in the state of equilibrium. The Contents of Meshshrungyadi kwatha have Dipan, Pachan, Vedanasthapan \& Vat-shamak properties ${ }^{6}$ which Helps in bringing back the viated doshas in the state of equilibrium along with Agnikarma.

\section{1) Upkarana:Lohashalaka}

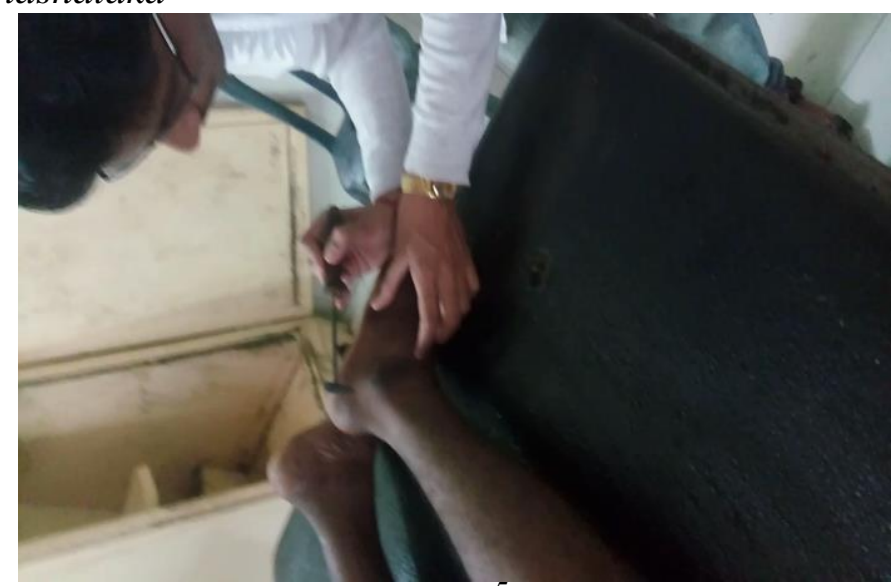

2) Agnikarma Sthan: "Antarakandaragulpha",5

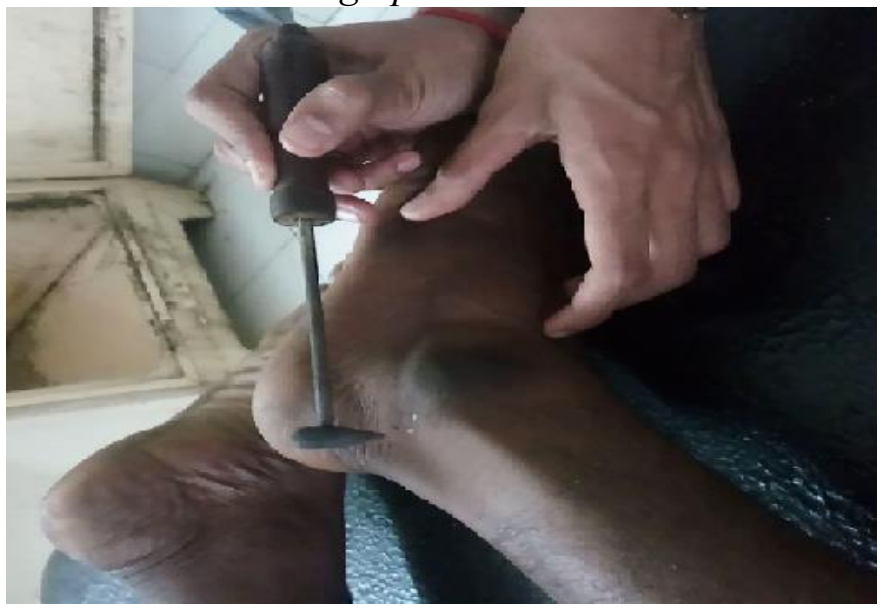




\section{Conclusion}

Since the therapy for Grudhrasi has limitation in other pathies, the unique combination of Ayurvedic herbs kwatha and Agnikarma can be effective therapy in Grudhrasi.

\section{References}

[1] Charaka samhita, edited with 'charaka-chandrika' hindi commentary by Dr.Brahmanand tripathi,Chaukhamba surbharati prakashan Varanasi,reprint 2016, vol I sutra sthan, maharogadhyay 20/11,page no.389.

[2] Sushrut Samhita, edited with hindi commentary by Dr. Ambikadatta Shastri, Chaukhamba Sanskrit sansthan varanasi, reprint 2017, Nidansthan, Verse no. 1/74, Page no.303

[3] Vavgasena by pandit Hariprasad tripathi,chaukhamba Sanskrit series varanasi, Reprint 2016 (2nd edition), vatvyadhi adhikara, shloka 584-585, page no.706.

[4] Sharangdhar samhita, edited with Jiwanprada hindi commentary by Vd. Smt.Shailaja Shrivastava, Chaukhamba Orientalia publication Varanasi, reprint 2015, Madhyamkhanda, Verse no. 2/1-2, Page no.135.

[5] Charaka samhita, edited with 'charaka-chandrika' hindi commentary by Dr.Brahmanand tripathi,Chaukhamba surbharati prakashan Varanasi,reprint 2017, vol II chikitsa sthan, vat vyadhi chikitsadhyay 28/101,page no.956.

[6] Dravyaguna vijnana vol II by Prof.P.V.Sharma,Chaukhamba bharati academy,reprint 2017,page no 1)103, 2)503, 3)632, 4)763, 5)58, 6)455, 7)282, 8)280 .

*Corresponding author.

E-mail address: gauravkumar.shaha@ gmail.com 